\title{
X-linked spastic paraplegia type 16
}

INSERM

\section{Source}

INSERM. (1999). Orphanet: an online rare disease and orphan drug data base. $\underline{X \text {-linked }}$ spastic paraplegia type 16. ORPHA:100997

A complex, hereditary, spastic paraplegia characterized by delayed motor development, spasticity, and inability to walk, later progressing to quadriplegia, motor aphasia, bowel and bladder dysfunction. Patients also present with vision problems and mild intellectual disability. The disease affects only males. 